\title{
The tree as evolutionary icon: TREE in the Natural History Museum, London
}

\author{
NILS PETTER HELLSTRÖM \\ Department of History and Philosophy of Science, University of Cambridge, Free School Lane, Cambridge, \\ CB2 3RH, UK (e-mail: petterland@gmail.com).
}

\begin{abstract}
As part of the Darwin celebrations in 2009, the Natural History Museum in London unveiled TREE, the first contemporary artwork to win a permanent place in the Museum. While the artist claimed that the inspiration for TREE came from Darwin's famous notebook sketch of branching evolution, sometimes referred to as his "tree of life" drawing, this article emphasises the apparent incongruity between Darwin's sketch and the artist's design - best explained by other, complementary sources of inspiration. In the context of the Museum's active participation in struggles over science and religion, the effect of the new artwork is contradictory. TREE celebrates Darwinian evolutionism, but it resonates with deep-rooted, mythological traditions of tree symbolism to do so. This complicates the status of the Museum space as one of disinterested, secular science, but it also contributes, with or without the intentions of the Museum's management, to consolidate two sometimes conflicting strains within the Museum's history. TREE celebrates human effort, secular science and reason - but it also evokes longstanding mythological traditions to inspire reverence and remind us of our humble place in this world.
\end{abstract}

KEY WORDS: Charles Darwin - Richard Owen - tree of life - science and religion - science and art.

\section{INTRODUCTION}

In March 2009, to celebrate Charles Darwin's bicentenary, the Natural History Museum, London, unveiled TREE (Figure 1). ${ }^{1}$ This work by Tania Kovats, the first permanent contemporary artwork at the Museum, was installed on the ceiling of the Mezzanine Gallery. TREE consists of a thin, longitudinal section of an oak tree. Not only is it a remarkable technical achievement, it also marks the latest stage of a development in which Richard Owen's museum has been transformed into a Darwinian stronghold. This essay examines TREE in relation to its purported origin in one of Darwin's tree-like doodles of evolutionary history, and seeks a place for the new ceiling not only within the history of the Natural History Museum itself but also within contemporary struggles surrounding science and religion.

\footnotetext{
* An earlier version of this paper was awarded the William T. Stearn Student Essay Prize of the Society for the History of Natural History for 2010. This prize, instituted in honour of the late William T. Stearn, a scholar whose work contributed much to the history of natural history and to this Society, is awarded annually to the best original, unpublished essay written by an undergraduate or postgraduate student.
} 


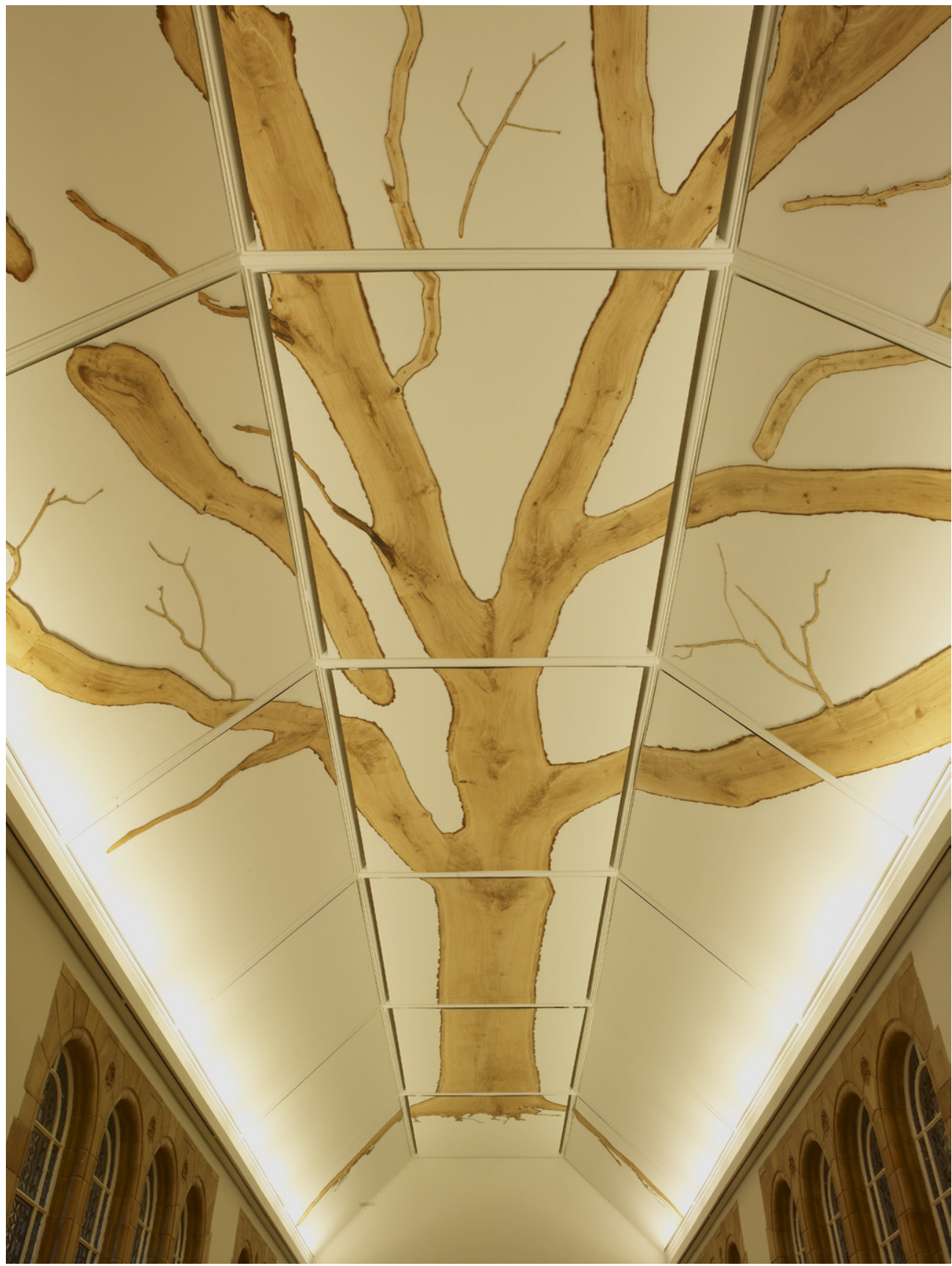

Figure 1. TREE on the ceiling of the Natural History Museum, London. (C Reproduced by permission of the Trustees of the Natural History Museum, London.) 


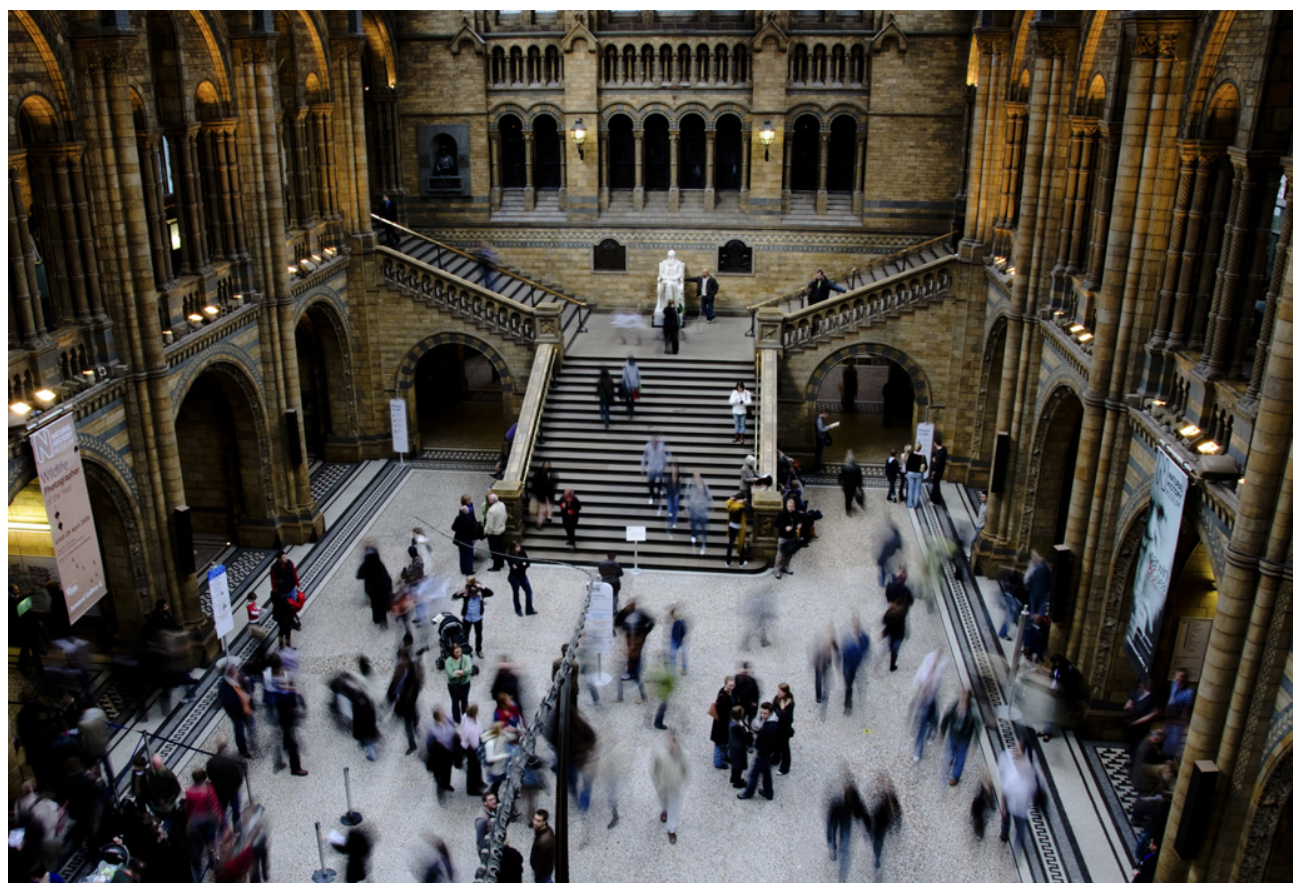

Figure 2. The Central Hall of the Museum. Darwin's statue is on the staircase landing. The statues of Huxley and Owen are on either side of Darwin, up the stairs and out of sight. The Tree Gallery is behind him. (C) Gary Jones; reproduced by courtesy of Gary Jones and by permission of the Trustees of the Natural History Museum, London.)

\section{DARWIN IN THE NATURAL HISTORY MUSEUM}

Large sums were spent on Darwin in 2009, and large sums were also made from him: academics arranged conferences and inaugurations; the authorities minted coins and printed stamps; money-makers sold us mugs, stickers, t-shirts, shows, and, of course, a feature film. The bicentenary celebrations thus accelerated a process of celebrity-making that had begun in Darwin's own life time. This acceleration has been dramatic, as the increasing familiarity of Darwin's portrait suggests: Browne (2009) has shown that photographs and other images of Darwin were already circulating in his own era, but that the iconic status of his face is more recent. One decisive step was Darwin's succession in 2000 to the Bank of England's $£ 10$ bank note, replacing Charles Dickens.

As Darwin's birthday was the occasion, it may be justified to ask whether we were celebrating his scientific contributions or his person. Such a distinction, however, may be impossible to uphold. Darwin is not primarily a person but has become, in the metaphor most suitable to our era, a "global brand" (Desmond and Moore 2009: xv). But the brand is ambiguous. Is Darwin to be celebrated as scientific genius, truth-telling saint of secularism, moral and national hero, or perhaps as an artist - as Kovats fascination with Darwin's moments of wordless inspiration seems to indicate? ${ }^{2}$ The ambiguity is only to be expected, however, considering the plurality of interested parties, all dragging Darwin along in their own preferred directions. Not least the British state has been active: bank notes, coins, stamps, museums and monuments are the more recent examples, but we should not forget earlier appropriations, such as Darwin's burial in Westminster Abbey. Many have stressed 
the universal character of the Darwin celebrations - Shapin (2010), apparently forgetting Christmas, mentioned "history's biggest birthday party" - but they may have been far more local than some would admit. Even so, they were peculiar celebrations, bound up with political struggles over the place of religion in contemporary society, as Shapin (2010), Secord (2009) and Kjærgaard (2009) have all reminded us.

TREE, importantly, was not the only striking Darwin celebration at the Natural History Museum in London. Most prominently, the Museum's eight-storey Darwin Centre, housing the Museum's scientists and collections and constituting "the most significant development at the Museum since it moved to South Kensington in 1881 "3, was inaugurated in 2009. More symbolically, in the previous year, the Central Hall witnessed a preparatory relocation of statues, in which the blackened bronze statue of Richard Owen, the Museum's founder, lost its privileged place on the staircase landing to Darwin's white marble one. ${ }^{4}$ This revoked the arrangement from 1927, when Darwin's statue had been ousted from the same place to make way for Owen's. As visitors now enter the majestic, nave-like Central Hall, they face Darwin's statue elevated at the far end, his figure seated as if on a throne, overlooking the Hall (Figure 2). Flanking Darwin, but not immediately visible, are the statues of Huxley and Owen, and behind Darwin is the Tree Gallery, as the Mezzanine Gallery is now known. Not everyone was happy when the Museum's founder was removed. ${ }^{5}$ Even so, the new arrangement is likely to remain. ${ }^{6}$

Today, Darwin and evolutionary theory is at the heart of the Natural History Museum. But in 1881, when the Museum first opened to the public, it did not celebrate evolution but divine creation. Owen, the prime mover behind the new museum in South Kensington, was a prominent naturalist whose understanding of nature was religious and taxonomic rather than evolutionary. Due to his scientific authority and personal zeal, his view of nature fundamentally shaped the new museum - often in open conflict with other naturalists, such as Darwin and Huxley (Yanni 1999: 111-113, 128-130; Rupke 1994: 3, 99-105). This bitter struggle is sometimes described as one for or against evolutionary theory, notably by the Museum itself. ${ }^{7}$ But the irreconcilability of Darwin's and Owen's science has long been questioned (MacLeod 1965; Ospovat 1981; Desmond 1989), and it has been argued that the conflict was primarily about institutional influence - with the scientific irreconcilability exaggerated to fit the story of the Darwinians (Rupke 1994: 1-11).

Owen's marked influence on the Museum, combined with the distinct mediaeval ecclesiastical style of architect Alfred Waterhouse (Stearn 1981: 45), ensured it is still today known as a "cathedral of nature". This is mainly because the Central Hall reminds the visitor of a nave, lit by stained glass windows and flanked by twelve bays "resembling sidechapels" (Stearn 1981: 57). As a result, some visitors have been known to remove their hats when entering the building (Stearn 1981: 47). Also the contemporary Victorian press was appreciative of the building's religious allusions, and biblical references were commonplace in coverage of the Museum (Yanni 1999: 143-144). An editorial in The Times, for example, made references to Noah's ark, outdoor worship and church architecture and declared the new museum "a true Temple of Nature, showing, as it should, the Beauty of Holiness" (Anonymous 1881: 9). Nature, however, a journal closely allied with the Huxley party within science (Yanni 1999: 143), disapproved of the design: "Greatly as we admire the spacious hall, the grand staircase, the long colonnades, and the picturesque colouring of the whole building, we cannot but feel that the adoption of such a semi-ecclesiastical style was a mistake" (Anonymous 1882: 55). In spite of such criticism, the Darwinians moved into Owen's "temple" after his retirement in 1883. The new director, William Flower, brought 
exposition of evolutionary theory to the Museum (Stearn 1981: 76), and in 1885, with unmistakable symbolism, the marble statue of Darwin was installed on the stairs of the Central Hall (Anonymous 1885: 10), where it stood until 1927.

Internal struggles have since transformed the Museum into a Darwinian stronghold. This past is also reflected in the self-image of the Museum's management. On the Museum's website, the history of evolutionary theory is presented as a struggle between science and religion, the latter represented by "the Church", with the public debate between Huxley and Bishop Samuel Wilberforce at its climax. ${ }^{9}$ Website visitors are told how evolution, even if now "accepted by the scientific community", once "challenged the biblical account of creation taking place in six days, a belief that had been dominant in Western Christian societies for thousands of years". This should be related to the Museum's position statement on evolution, which endorses evolutionary theory as "the best current explanation for how the diversity of life around us came to be". ${ }^{10}$ The same statement advocates evolutionary theory as a core part of the science curriculum of British schools, and opposes the teaching of creationism and intelligent design as science. Such hopes for policy change were to some degree satisfied in November 2009, when the British government announced that from September 2011 the teaching of evolution will be compulsory in state primary schools (Hurst 2009).

\section{DARWIN'S CANOPY}

For the Darwin bicentenary, the Natural History Museum announced a competition for an artwork to be installed on the ceiling of the Mezzanine Gallery. Inspiration for the work was to come from Darwin, and the result would be the first permanent contemporary artwork to have a place in the Museum. In a press release for "Darwin's Canopy", as the project was called, the project leader and Head of Special Projects and Innovation at the Museum, Bob Bloomfield, described the ceiling as "a fantastic blank canvas for a modern-day homage to Darwin's achievements". 11 The press release also disclosed how the winning artwork would "be revealed as a highlight of the celebrations on Darwin's birthday". When asked about the motivations behind the project, Bloomfield maintained that "Darwin's Canopy" was not meant to celebrate the person Darwin, but "the objective, scientific evidence" of the theory of evolution, and stressed the importance of the coincident 150th anniversary of the publication in 1859 of Darwin's On the origin of species. ${ }^{6}$ Bloomfield, who was also responsible for returning Darwin's statue to the Central Hall stairs in 2008, explained the project in terms of a conflict between science and religion, personified as a conflict between Darwin and Owen: "We wanted to place Darwin's idea at the heart of the building, which had been built by Owen as a celebration to creation." Bergit Arends, Curator of Contemporary Art at the Museum, expressed a similar sentiment when she explained that "Darwin's thinking is at the heart of the Museum [which] required a particular statement". ${ }^{12}$

Thirty-seven artists were nominated to participate in "Darwin's Canopy". In January 2008, the Museum asked ten of them to develop their proposals. To prepare the selected artists, the Museum invited them to a two-day workshop on Darwin and evolutionary theory, and granted them access to its libraries and collections. The final proposals were exhibited to the public between 4 June and 14 September 2008, but this was not a component of the competition because by mid-June TREE had been unanimously selected by an expert panel and announced as the winner. ${ }^{13}$ According to the Museum, four factors had guided the 


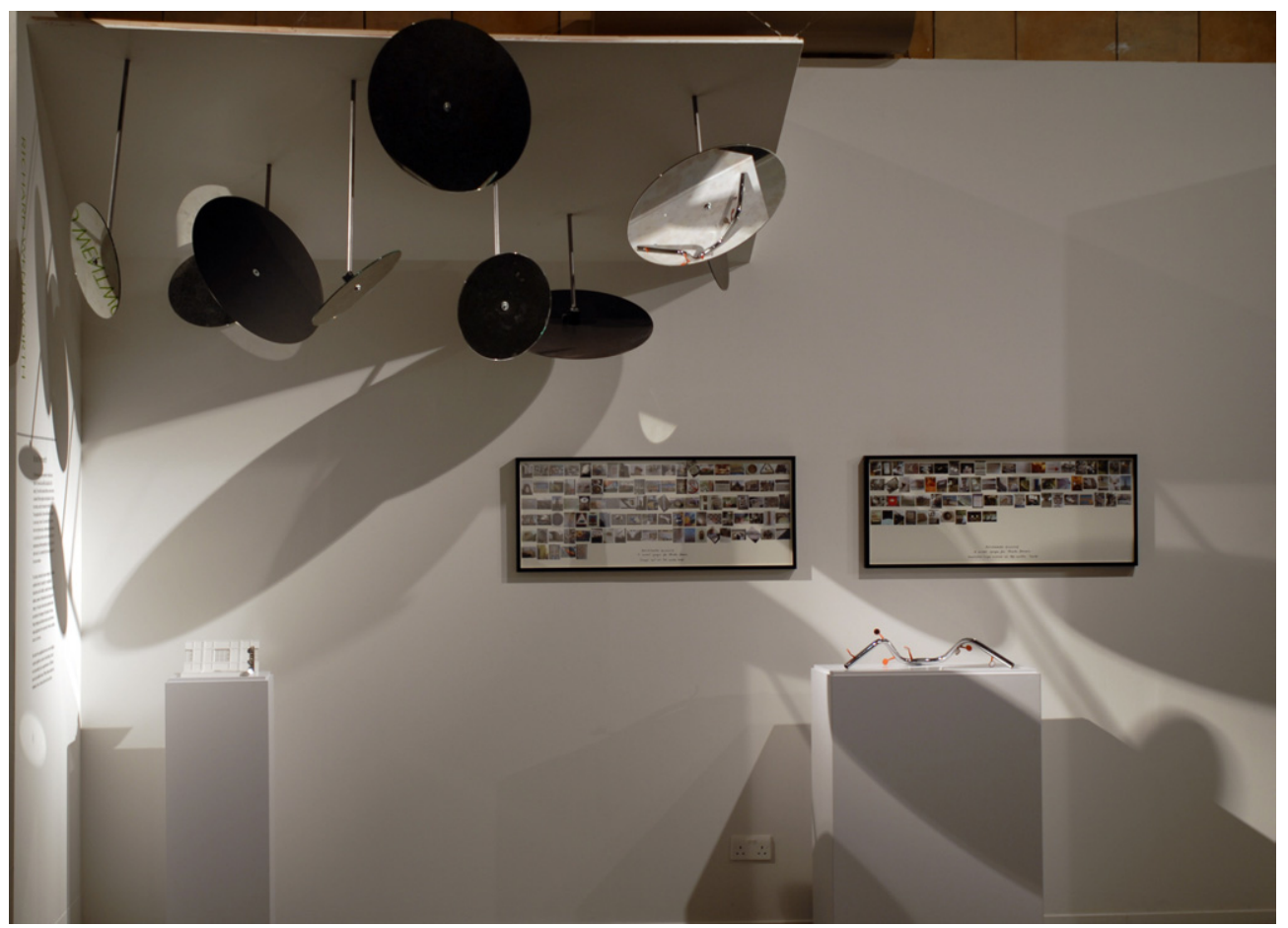

Figure 3. Detail from Richard Wentworth's proposal for "Darwin's Canopy", named "Out of the corner of the eye (for Darwin)". (C Reproduced by permission of the Trustees of the Natural History Museum, London.)

decision: the quality of the work itself; how well the work encapsulated Darwin's ideas, including their contemporary significance to how we understand the natural world and our place within it; how well the work responded to the architecture of the building; and whether it could be completed in time for Darwin's birthday. Bearing the outcome in mind, let us pause and consider what the ceiling may have looked like if Kovats had not won.

Of the ten finalists, only one did not engage with evolution. ${ }^{14}$ Richard Wentworth's "Out Of The Corner Of The Eye (For Darwin)" instead wanted to celebrate Darwin's vigilance and powers of observation. This would be achieved by numerous small mirrors installed on the ceiling, mounted like rear view mirrors to stimulate peripheral vision and new perspectives - but also to allude to the experiences of urban cyclists (Figure 3). The other nine contestants all tailored their proposals to the theme of evolution. Dorothy Cross's "Darwin Column" was an image of inheritance and evolution: a clear-glass column with an engraved human skull, containing a foetal skeleton where the brain should be. Mark Fairnington suggested twelve painted eyes of different animals; partly to invoke Darwin's comments in Origin about the incomprehensible evolution of the eye, and partly to celebrate visual observation in scientific and artistic practices. Alison Turnbull proposed a sequence of aluminium panels that changed gradually from white to black, with some interventions of bright colours; her work was informed by the many references to colour in Darwin's account of the Beagle voyage, and by the famous case of the peppered moth during the industrial revolution (it changed from white to black to adopt to pollution). 


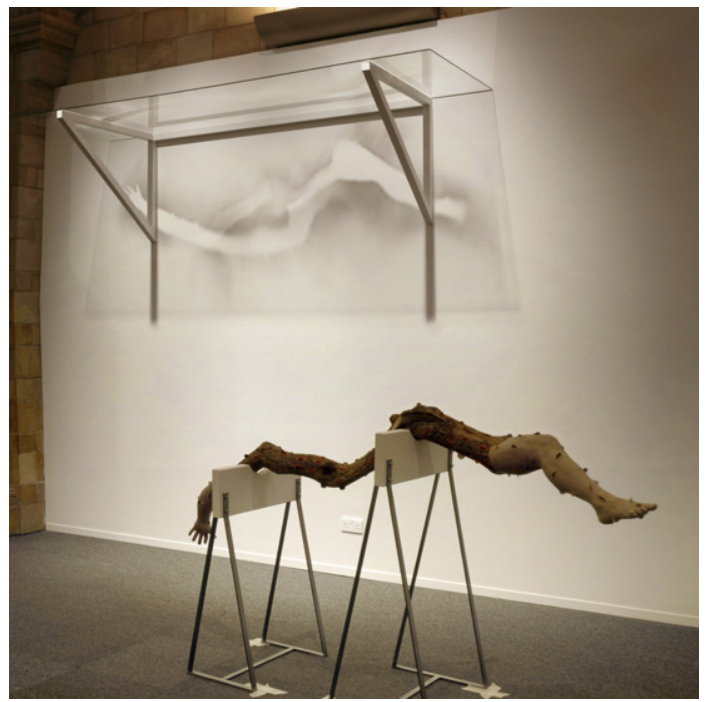

Figure 4. Detail from Christine Borland's proposal for "Darwin's Canopy", entitled "We Think". (C) Reproduced by permission of the Trustees of the Natural History Museum, London.)

UnitedVisualArtists, a collective best known for light installations, proposed to project an evolving ecosystem on the ceiling. Mark Wallinger wanted to inscribe the entire Oxford book of English verse 1250-1918 on a suspended ceiling, with telescopes and binoculars supplied to visitors; a reference to the prominent position of nature in English poetry, and to the evolution of poetic expression (the press kit also pointed out that the poetry collection concerned was at one point known as the "Atheist's Bible"). Rachel Whiteread proposed to cover the ceiling with panels featuring indented footprints of humans and animals. Richard Woods wanted to adorn the ceiling with ceramic tiles in a wide variety of styles portraying the natural world, thus comparing the evolution of decorative styles to that of species. Christine Borland, perhaps most interestingly, submitted a design for a sculpture modelled on "the key tree of life image", referring to the same sketch as Kovats. Borland's tree would have human limbs and visitors would be asked to insert coins into it, in reference to a South American wishing-tree described by Darwin. In a second stage, the shadow of the tree would be traced in glass panels suspended from the ceiling, and the metal from the coins would be melted down to produce a plaque, inscribed "We Think 1809-2009" (Figure 4). ${ }^{14}$

Amongst the nominees were some of Britain's most established artists: Wallinger and Whiteread have both won the prestigious Turner Prize for contemporary $\operatorname{art}^{15}$, and both have represented the UK at the important Venice Biennale, as has Borland. ${ }^{16}$ Works by Borland, Cross, Turnbull, Wallinger, Wentworth and Whiteread are in the national Tate Collection ${ }^{17}$, and several of the artists have carried out large-scale public commissions. Some of the artists may thus have been short-listed, at least in part, because of their repute; Museum press releases and media reports repeatedly referred to Wallinger and Whiteread, but not to the other nominees. ${ }^{18}$ Publicity, not only art, was clearly at stake.

While Fairnington had worked with the Museum in the past and was exhibited there in 2004, Kovats stood out amongst the nominees with a documented interest in Darwin. In 2007 she edited The drawing book, in which she introduced the chapter on nature drawings 

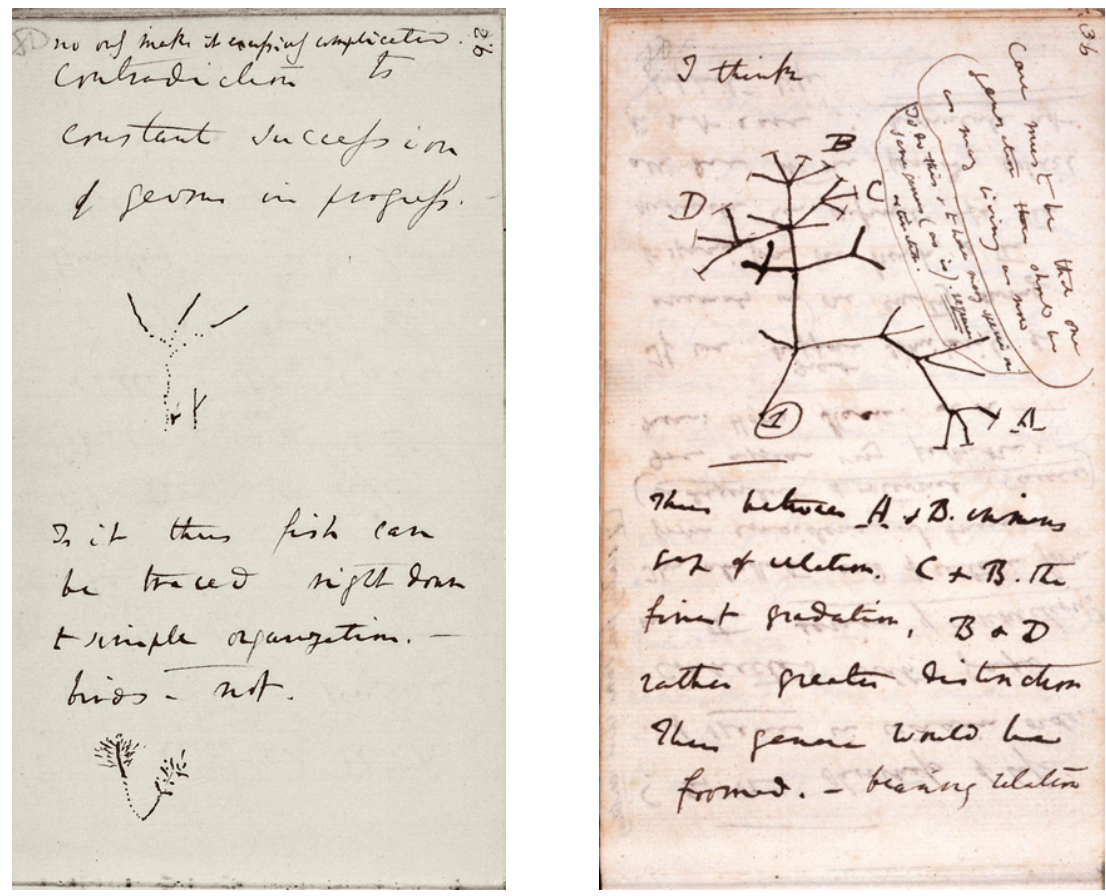

Figure 5. Darwin's first known attempts to represent evolution graphically on pages 26 and 36 in his B notebook, kept in 1837-1838. The sketch to the right is referred to as Darwin's "tree of life" drawing by the Museum. It is immediately preceded by the phrase "I think" and a note on extinction is scribbled almost on it. MS.DAR.121. (C) Cambridge University Library; reproduced by permission of the Syndics of Cambridge University Library.)

with one of Darwin's 1837 sketches of branching evolution (Kovats 2007: 88), the same drawing that later formed the basis for her work with TREE (Figure 5). Kovats, moreover, learnt about her nomination for "Darwin's Canopy" one day before she left for South America with Darwin's Voyage of the Beagle (1839) as a travel companion. ${ }^{19}$ Apart from a long-standing and outspoken interest in Darwin, her previous work had displayed a concern for nature, landscape and ecology. Kovats's suitability as an ally may thus have influenced the panel's appreciation of her proposal. Indeed, the Natural History Museum is not only a bastion of Darwinism, it has also made itself a champion for sustainability and ecology: recent position statements on climate change and biodiversity loss are two examples. ${ }^{20}$ Yet, to understand fully the potency of TREE, and why the Museum found it appropriate for their project, we need to investigate the symbolism of Kovats's work.

\section{THE TREE OF LIFE}

Kovats claimed that her main source of inspiration for TREE was one of Darwin's first drawings of branching evolution, sketched in his first notebook on transmutation and immediately preceded by the inscription "I think" (Figure 5: right). This claim was reiterated in the publicity material from the Museum. "The making of TREE", a video displayed at the gallery entrance and featured on the Museum's website, presents Kovats's claim 
pedagogically: it ends with pictures of TREE that first fade into a leafless back-lit real tree and finally into Darwin's drawing. ${ }^{21}$ Yet the claim is problematic: it is questionable that an abstract, sprawling sketch alone made the artist think of an oak tree, especially as the sketch is not visually suggestive of a mature tree and also was not named a tree by Darwin himself. Thus, while Darwin's sketch may have been one source of inspiration, it cannot have been the only one. Within the immediate field of natural history, for example, Kovats's design is markedly more reminiscent of Haeckel's "Systematischer Stammbaum des Menschen" (Haeckel 1874) (Figure 6) than it is of Darwin's drawing, especially when Kovats's original idea for TREE is considered (Figure 7). Haeckel was the first to translate Darwin's work into phylogenetic diagrams that looked like and were called trees. ${ }^{22}$ In fact, it is unlikely that Kovats would have seen a tree in Darwin's sketch had it not been for Haeckel.

The eagerness with which the connection between Darwin's sketch and Kovats's design is made - despite the obvious discrepancy - is puzzling. Yet it may, at least in part, be explained by the importance attributed to this particular Darwin sketch: the Museum claims it was "the first sketch Darwin drew to try to explain his ideas of evolution". ${ }^{23}$ But in fact there are three branching sketches illustrating evolution in the same notebook, and contrary to the claim that the particular drawing was the first, it was in fact the last of the three. The earlier sketches are both on page 26, the latter on page 36 (Barrett et al. 2008: 177, 180). All three are abstract doodles that could be suggestive of plant growth, but not of mature trees (Figure 5). Moreover, as Gruber (1978: 126) pointed out, none was drawn to illustrate

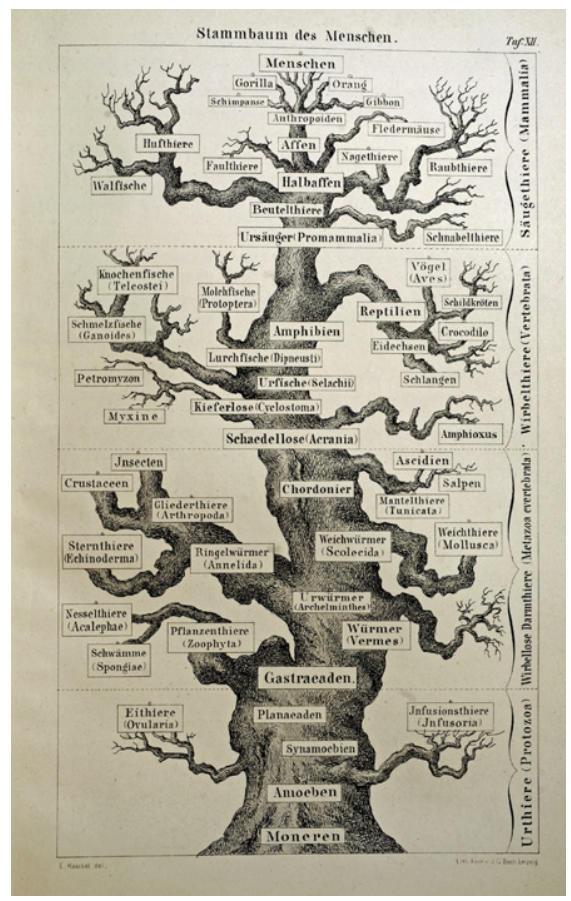

Figure 6. Haeckel's "Systematischer Stammbaum des Menschen" (1874). (C) Library of the Royal Swedish Academy of Sciences in Stockholm University Library; reproduced by permission.)

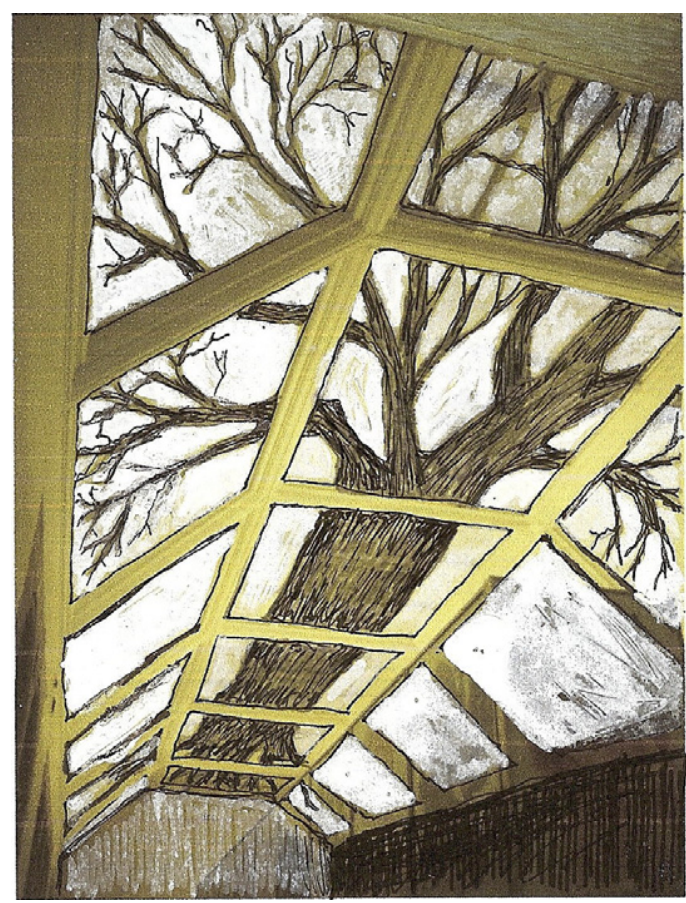

Figure 7. Kovats's sketch for TREE, submitted for the "Darwin's Canopy" competition. (C) Reproduced by courtesy of Tania Kovats.) 
evolution as such, but rather aspects of it: the first drawing illustrated evolutionary adaptations to air, land and water; the second, the long gaps in the fossil record; and the third, extinction. Gruber supported his argument using the text entries surrounding the sketches, including the comment on extinction scribbled next to the third diagram. It follows from this that no drawing in the 1837 notebook can be described as a first sketch of evolution, they come as a group. To claim the third drawing as the first while pretending not to know about the other two could perhaps be explained by aesthetic preferences, but it may also reveal a preference for simplified stories and unambiguous beginnings.

Another oddity accompanies the particular sketch: in the publicity material from the Museum, this drawing is repeatedly referred to as Darwin's "tree of life" drawing. ${ }^{24}$ This is misleading as Darwin did not label or refer to any of his sketches or diagrams as a "tree of life". But although he did not use the phrase for his diagrammatic representations, it was part of his vocabulary, as a simile for genealogical descent. Gruber (1978: 135) proposed that behind Darwin's thinking was "a group of images of wide scope" capable of "assimilating ... a wide range of perceptions, actions, ideas." As one of these images, the "tree of life" served him as an "image of nature deployed in evolutionary time" (Gruber 1978: 130). Darwin used the expression on several occasions in his notebooks of the late 1830s (Barrett et al. 2008: 176-177, 235, 285, 352), and, perhaps more famously, at the end of the chapter on natural selection in Origin (Darwin 1859: 129-130):

\footnotetext{
The affinities of all the beings of the same class have sometimes been represented by a great tree. I believe this simile largely speaks the truth. ... As buds give rise by growth to fresh buds, and these, if vigorous, branch out and overtop on all sides many a feebler branch, so by generation I believe it has been with the great Tree of Life, which fills with its dead and broken branches the crust of the earth, and covers the surface with its ever branching and beautiful ramifications.
}

Origin included a diagram to illustrate branching evolution, famously the only illustration in the book. This diagram was even less suggestive of a tree than the notebook sketches, and despite preceding the passage just quoted by only a few pages, and although it related to the same topic, Darwin referred to it as "the diagram". Darwin, then, did not equate his "diagram" to his "Tree of Life" simile. But they were also not wholly separate; instead he allowed for "resonance" between the two (Brink-Roby 2009: 267). ${ }^{25}$ The distinction between text and diagram was no oddity: many naturalists, including Bonnet (1766: 50), Pallas (1766: 23-24), Buffon (1766: 335) and Lamarck (1809: 462), used metaphorical tree language similar to Darwin's, but that did not mean that they drew diagrams that were reminiscent of trees, and even when tree language coincided with branching diagrams - most notably in Lamarck (1809: 463) - it did not follow that the diagrams were described as trees (see also Voss 1952: 15-17; Barsanti 1992a: 91-96, 1992b: 284-292). As Darwin alluded to in the passage quoted above, trees had previously been used to represent affinities of beings (for trees in natural history before Darwin, see Voss 1952; Stevens 1983; Barsanti 1992a; Voss 2007; Archibald 2009; Ragan 2009). Darwin, however, developed his tree simile further than previous naturalists had done. He also gave it a characteristic name, calling it "the great Tree of Life".

The tree is a recurrent and deep-rooted symbol. It permeates mythology (James 1966; Cook 1974; Schama 2004), genealogy (Watson 1934; Bouquet 1995, 1996; Klapisch-Zuber 1991, 2000, 2007) and science (Voss 1952; Barsanti 1992a; Hacking 2007; Ragan 2009). It takes its authority from repetition and conflation; metaphorical and symbolic trees have appeared in similar but ever-changing manifestations since antiquity. Predecessors have served to explain and naturalize successors. In this protracted history of metaphorical trees, 
the tree of life was no Darwinian innovation but had reappeared as a mythological trope and symbol for cosmic unity at least since the civilizations of ancient Egypt and Mesopotamia (James 1966). In one of its more renowned manifestations, the tree of life had grown at the centre of the Judeo-Christian god's creation - and thus at the heart of western imagination. Genesis, the first book of the Bible, tells how the Lord planted it in the midst of the garden of Eden, close to the tree of knowledge of good and evil (Genesis 2: 9, 17; 3: 22-24). ${ }^{26}$

I have shown elsewhere that Darwin named his evolutionary "tree of life" after its scriptural namesake. ${ }^{27}$ In doing so, Darwin mobilized one of the oldest and richest traditions of imagery available to him. To play consciously on religious tree imagery was no new trick: Ramon Llull (c. 1232-1315) had already done it in 1295 with that other Edenic tree in his book Arbor scientiae - thus the "branches" of our various sciences - but still it helped Darwin to seize the imagination of his readers. ${ }^{28}$ In a different but similar way, the diagram in Origin related to earlier graphic conventions, both scientific and religious. Conspicuously, it integrated all the three traditions discussed by Barsanti in La scala, la mappa, l'albero (1992a): it proceeded upwards in clearly delineated steps; it mapped relations in stylized form; it ramified. ${ }^{29}$ This conflation of traditions may provide one clue to the ambiguous role of hierarchy in Darwin's diagram in Origin, as observed by Brink-Roby (2009: 260-261). At the same time, the adoption of the tree simile and the tree diagram by Darwin and other evolutionists shows how scientific discourse is rooted in "local cultural discourse", as argued by Bouquet (1995: 44).

Many have expressed dissatisfaction with the current state of affairs. Gould (1997: 42) asserted that: "I know no other subject so distorted by canonical icons: the image we see reflects social preferences and psychological hopes, rather than paleontological data or Darwinian theory." Bredekamp (2005), also concerned with the implications of the tree model, has argued that Darwin's diagrams, and thus his thinking, were not based on trees but on corals. Supporting his argument with an early notebook passage where Darwin considered the "coral of life" as an alternative to the "tree of life" (Barrett et al. 2008: 177), Bredekamp made visual comparisons, claiming that Darwin's diagrams are more coralline than arboreal. Yet the strongest criticism of the tree model has come from evolutionary scientists, notably Doolittle $(1999,2000,2010)$, on the grounds that the tree model misrepresents evolutionary reality (see also Bapteste et al. 2009; O'Malley et al. 2010). Even Kovats had reservations, if primarily about the phrase "tree of life", which "doesn't feel appropriate" to her, given its religious connotations. ${ }^{30}$ Kovats further believed that the notebook drawing "is probably a coral anyway, not a tree" - which may appear as contradictory, provided she still claimed the drawing as the basis for her work. In any case, Kovats was careful not to use the biblical phrase in relation to TREE, and asked the Museum to avoid it as well. She suspected that the reason why the Museum used it anyway was that it could serve as a "catch-phrase" to appeal to the public.

Despite many objections, and although seldom represented in the actual shape of a tree, the "tree of life" remains omnipresent, especially in popular representations of evolutionary theory. Recent British examples include the Wellcome Trust's interactive "Tree of Life" web-tool, the "Tree of Life" posters distributed by the Open University (humanity represented by Darwin), and "Charles Darwin and the Tree of Life", the 2009 BBC television documentary presented by David Attenborough. The "tree of life" has indeed become a "canonical icon" of evolution, as argued by Gould (1997). But it is a tangled and multi-layered one. In 1859, Darwin marshalled deep-rooted religious, mythical and cultural references to promote his theory of evolution. When the Museum commissioned 
TREE to celebrate Darwin and secular science a century and a half later, they repeated his move.

\section{CONCLUDING TREE}

TREE is a thin, longitudinal section of an oak tree from the Longleat forest (Figure 8), which Kovats and her team felled, uprooted, planked, shaved, dried, sanded, waxed and mounted on aluminium plates (Figure 9), which were then attached to the ceiling. This process complicates any definite division between nature and culture: TREE is both grown and manufactured; it is organic, real and three-dimensional, but also a two-dimensional representation of itself, stripped of foliage, bark, twigs and smaller branches, and, of course, purged of fungi, insects, birds and squirrels. The height of the tree is also restricted by the construction and dimensions of the gallery: its root system has been severed and the joints testify to reassembling. TREE is a human-made object; it is dead, as is everything else on display in the Museum, but it reminds us of life in a way that mirrors, computer simulations and painted eyes would not have been able to do.

There is something peculiar at stake here, as TREE not only illustrates Darwin's theory, but also the impetus behind the Museum: to bring nature under the human eye. Kovats has stated that specimen preparation influenced her work and suggested that one understands TREE as "a large botanical specimen." 31 TREE indeed appears like a macroscopic microscope slide, or, if one would like, as a magnified micro-organism. But there are also extra-scientific references at play here. Installed on the ceiling of a cathedral-like building, it calls attention to tree symbolism in church architecture. The painting on the ceiling of Ely cathedral and the stained glass windows at Canterbury are spectacular examples of the tree of Jesse imagery commonly found in churches and cathedrals. ${ }^{32}$ Such iconographic representations of prophecy and Christ's ancestry are typically abstract and visually very

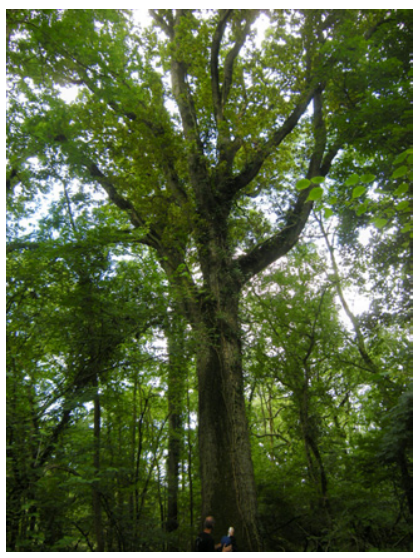

Figure 8 . The oak that was to become TREE - Quercus $\times$ rosacea - grew in the Longleat forest, Kent. (C) Reproduced by courtesy of Tania Kovats.)

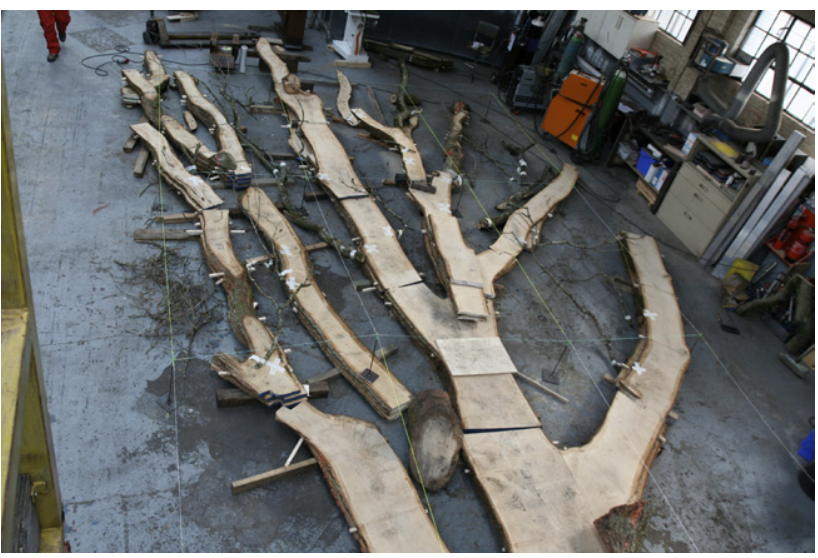

Figure 9. The oak was felled, uprooted, planked, shaved, dried, sanded, waxed and mounted on aluminium plates. TREE taking shape at Mike Smith Studios, south London. (C) Reproduced by courtesy of Tania Kovats.) 
different from Kovats's design, but they are still trees, and important in this context insofar as they constitute the origins of the genealogical tree and thus of the evolutionary tree. ${ }^{33}$

TREE was made from an oak. This species was chosen, according to Kovats, because oaks are big, old, "iconic", and "important in British culture and landscape". ${ }^{11}$ The oak is indeed a national symbol of England. But as already alluded to, the choice of an oak to represent evolution also aligns TREE, visually, with Ernst Haeckel's "Systematischer Stammbaum des Menschen" (Haeckel 1874). Kovats's oak, and even more so her original sketch for the work, is certainly more reminiscent of Haeckel's tree - accused of polluting Darwinian theory with teleology and anthropocentrism (Gould 1997) - than it is of Darwin's notebook sketch. When asked about the resemblance, Kovats said that she recognized Haeckel's tree, but that it had not influenced her work, at least not consciously. ${ }^{19}$ The critic may find it hard to detect Darwin's sprawling sketch in Kovats's mature tree, but it is perhaps even harder to imagine how TREE would have conveyed the same undertones of sanctity, myth, pedigree, majesty, heritage, time, hierarchy and ecology - had Kovats remained faithful to Darwin's notebook sketch, his diagram, or, say, a coral. Thus, it is the interplay of TREE with extra-scientific traditions that makes it rich.

Yet TREE is not only a symbol, but also a real tree, and it is difficult, of course, to trace hierarchies of progress and meaning in a tree that did not grow to convey them. Kovats said that she considered her tree to be "anti-representational". ${ }^{19}$ And indeed, it is hard to reduce a real tree to mere representation. It can remind visitors of smell, touch and taste in a way that more artificial trees cannot; it is able to conjure images of the woods. And although the installation was made substantially more sterile by the removal of a display of insects and leaves found in and on the living oak, the accompanying video, leaflet and website still call the visitor's attention to woodland life-cycles and the material character of the work. Thus, when asked if TREE risked propagating a sense of hierarchy in nature, Kovats was able to reply by referring to the woods and the felled tree: "Because the tree came down there is now a pond there, surrounded by saplings. The woods invade the empty space." 30 Due to Kovats's literal interpretation of the tree simile, her artwork is able to simultaneously take its authority from, breathe new life into and subvert the tradition it belongs to.

On 3 April 2009 the BBC broadcast a radio programme about TREE entitled "The Darwinian Sistine chapel". ${ }^{34}$ This perspective was well-rooted in the press coverage of the nineteenth century. But TREE can also remind us of a Christmas tree: ritually felled and brought indoors with the excuse of someone's birthday. ${ }^{35}$ With or without the intentions of the Museum's management, it thus seems that the new artwork is able to play on strings that are not strictly scientific - and thus to consolidate two trends in the Museum's history. TREE celebrates evolutionary theory, human effort, secular science and reason, but it also evokes long-standing mythological traditions to remind us of our humble place in this world and to inspire reverence. The Darwinians prevail, but they seem less foreign to the idea of a "cathedral of nature" than one may think. And like Darwin himself, they have understood the value of cultural resources in thinking, formulating and communicating scientific ideas.

\section{ACKNOWLEDGEMENTS}

I thank James Secord, James Moore, Tania Kovats, Bergit Arends and Bob Bloomfield - both of the Natural History Museum - and the Stearn Prize judges, Katherine Anderson, Brian Ogilvie and Anne Secord, as well as an anonymous referee. I am also indebted to Gillian Beer, Jesse Olszynko-Gryn, Jenny Bangham, Nick Hopwood, Francis Neary, Patricia Fara, Beryl Hartley, Adrian Desmond, Kathryn Ticehurst, Ayesha Hameed, and Camilla Jernmark. 


\section{NOTES}

${ }^{1}$ The unveiling took place on 19 March 2009, more than a month after Darwin's birthday on 12 February. URL (accessed 21 October 2010): http://www.nhm.ac.uk/about-us/press-office/press-releases/2009/tree-opens29856.html (Natural History Museum, 18 March 2009, “TREE opens”).

2 "The making of TREE", by Sally Weale and the Natural History Museum, 2009 [0:46].

${ }^{3}$ URL (accessed 21 October 2010): http://www.nhm.ac.uk/about-us/press-office/press-releases/2009/naturalhistory-museum-unveils-the-darwin-centre-at-royal-celebrations39028.html (Natural History Museum, 14 September 2009, "Natural History Museum unveils the Darwin Centre at royal celebrations").

${ }^{4}$ For an interpretation of the symbolism of black and white statues, see Rupke (1994: 1-4).

${ }^{5}$ R. Bloomfield (Head of Special Projects and Innovation at the Natural History Museum), pers. comm., 4 October 2010.

${ }^{6}$ R. Bloomfield, pers. comm., 8 January 2010.

${ }^{7}$ URL (accessed 20 October 2010): http://www.nhm.ac.uk/nature-online/evolution/how-did-evol-theorydevelop/evol-richard-owen/index.html (Natural History Museum, undated, "Richard Owen").

${ }^{8}$ URL (accessed 1 October 2010): http://www.nhm.ac.uk/visit-us/history-architecture/architectural-tour/ cathedral-of-nature/ (Natural History Museum, undated, "Cathedral of Nature").

${ }^{9}$ URL (accessed 21 October 2010): http://www.nhm.ac.uk/nature-online/evolution/how-did-evol-theorydevelop/the-story/index.html (Natural History Museum, undated, "The story").

10 "The Natural History Museum's position statement on evolution", dated June 2008. From the intranet of the Natural History Museum, enclosed in an e-mail from B. Arends, 12 January 2010.

${ }^{11}$ URL (accessed 21 October 2010): http://www.nhm.ac.uk/about-us/press-office/press-releases/2008/darwinscanopy 19031.html (Natural History Museum, 6 June 2008, "Darwin's Canopy”).

12 B. Arends (Curator of Contemporary Art at the Natural History Museum), pers. comm., 11 January 2010.

${ }^{13}$ URL (accessed 21 October 2010): http://www.nhm.ac.uk/about-us/news/2008/june/darwins-canopy-artworkselected12974.html (Natural History Museum, 15 June 2008, "Darwin's Canopy artwork selected").

${ }^{14}$ Darwin's Canopy press kit, provided on a USB memory stick at the opening of the exhibition, 3 June 2008 (by courtesy of J. Bangham).

15 The Turner Prize is one of the UK's most prestigious and publicized art awards. It is annually presented to a British visual artist under the age of 50 .

${ }^{16}$ URL (accessed 21 October 2010): http://venicebiennale.britishcouncil.org/people/section/decade/decade/all/ $\mathrm{bpa} / 0 /$ (British Council, undated, "UK at the Venice biennale").

${ }^{17}$ URL (accessed 13 October 2010): http://www.tate.org.uk/collection (Tate online).

${ }^{18}$ URL (accessed 21 October 2010): http://www.nhm.ac.uk/about-us/news/2008/february/museum-ceiling-toget-darwin-inspired-artwork18793.html (Natural History Museum, 9 February 2008, "Museum ceiling to get Darwin-inspired artwork"); URL (accessed 21 October 2010): http://www.nhm.ac.uk/about-us/news/2008/june/ darwins-canopy-unveils-ceiling-artwork-proposals12902.html (NHM, 10 March 2008, "Darwin's Canopy unveils ceiling artwork proposals"); URL (accessed 21 October 2010): http://www.nhm.ac.uk/about-us/press-office/pressreleases/2008/darwins-canopy19031.html (NHM, 6 June 2008, "Exhibits unveiled for new Museum artwork"); URL (accessed 21 October 2010): http://www.nhm.ac.uk/visit-us/whats-on/temporary-exhibitions/darwins-canopy/ (NHM, undated, "Darwin's Canopy: proposals for a new permanent artwork").

${ }^{19}$ T. Kovats, pers. comm., 22 January 2010.

${ }^{20}$ B. Arends, pers. comm., 27 January 2010.

21 "The making of TREE" [12:25].

${ }^{22}$ For Haeckel's phylogenetic trees, see Richards (2009).

${ }^{23}$ URL (accessed 21 October 2010): http://www.nhm.ac.uk/visit-us/galleries/green-zone/tree-gallery/ index.html (Natural History Museum, undated, "Tree: a ceiling masterpiece"); see also the TREE leaflet, distributed in the Tree Gallery, undated (available online from http://www.nhm.ac.uk/resources-rx/files/tree-leaflet1-30586.pdf).

${ }^{24}$ URL (accessed 21 October 2010): http://www.nhm.ac.uk/about-us/press-office/press-releases/2009/treeopens29856.html (Natural History Museum, 18 March 2009, “TREE opens”); also URL (accessed 21 October 
2010): http://www.nhm.ac.uk/visit-us/galleries/green-zone/tree-gallery/index.html (Natural History Museum, undated, "Tree: a ceiling masterpiece").

${ }^{25}$ For the importance of images in Darwin's work, see Voss $(2007,2010)$.

${ }^{26}$ For a botanical perspective on trees in the Bible, see Musselman (2007).

${ }^{27}$ N. P. Hellström, 2010 "Darwin and the tree of life: the roots of the evolutionary tree"; unpublished M. Phil. dissertation. Department of History and Philosophy of Science, University of Cambridge.

${ }^{28}$ The standard Latin rendering of the scriptural tree of knowledge is lignum scientiae, not arbor. For a discussion of this, see my M. Phil. dissertation.

${ }^{29}$ I owe this observation to Patricia Fara of Clare College, Cambridge. Also see Kuntz and Kuntz (1987).

${ }^{30}$ T. Kovats, pers. comm., 26 January 2010.

31 TREE leaflet (see note 23).

${ }^{32}$ For the tree of Jesse, see Watson (1934) and Klapisch-Zuber (2007: 295-296, 308). For the tree of Jesse in relation to royalty and power, see Johnson (1961).

${ }^{33}$ N. P. Hellström, 2010 Darwin and the tree of life: the roots of the evolutionary tree. Also see Bouquet (1996) and Klapisch-Zuber (2007).

${ }^{34}$ URL (accessed 17 October 2010): http://www.bbc.co.uk/programmes/b00jf3hj (BBC, undated, "The Darwinian Sistine chapel").

${ }^{35}$ On the pre-Christian roots of the Christmas tree, see James (1966: 91-92) and Cook (1974: 14-15).

\section{REFERENCES}

ARCHIBALD, J. D., 2009 Edward Hitchcook's pre-Darwinian (1840) "Tree of Life". Journal of the history of biology 42: 561-592.

ANONYMOUS, 1881 Untitled. The Times 18 April: 9.

ANONYMOUS, 1882 The new Natural History Museum. Nature 27: 54-56.

ANONYMOUS, 1885 The Darwin memorial statue. The Times 10 June: 10.

BAPTESTE, E., O’MALLEY, M. A., BEIKO, R. G., ERESHEFSKY, M., GOGARTEN, J. P., FRANKLIN-HALL, L., LAPOINTE, F. J., DUPRÉ, J., DAGAN, T., BOUCHER, Y. and MARTIN, W., 2009 Prokaryotic evolution and the tree of life are two different things. Biology direct 4: 34 .

BARRETT, P. H., GAUTREY, P. J., HERBERT, S., KOHN, D. and SMITH, S. (editors), 2008 Charles Darwin's notebooks, 1836-1844. Cambridge and London.

BARSANTI, G., 1992a La scala, la mappa, l'arbero: immagini e classificazioni della natura fra sei e ottocento. Florence.

BARSANTI, G., 1992b Buffon et l'image de la nature: de l'échelle des êtres à la carte géographique et à l'arbre génealogique, pp 255-296 in GAYON, J. (editor), Buffon 88: Actes du colloque international pour le bicentenaire de la mort de Buffon. Paris.

BONNET, C., 1766 The contemplation of nature. Volume 1. London.

BOUQUET, M., 1995 Exhibiting knowledge: the trees of Dubois, Haeckel, Jesse and Rivers at the Pithecanthropus centennial exhibition, pp 31-56 in STRATHERN, M. (editor), Shifting contexts: transformations in anthropological knowledge. London and New York.

BOUQUET, M., 1996 Family trees and their affinities: the visual imperative of the genealogical diagram. The Journal of the Royal Anthropological Institute 2 (1): 43-66.

BREDEKAMP, H., 2005 Darwins Korallen: Die frühen Evolutionsdiagramme und die Tradition der Naturgeschichte. Berlin.

BRINK-ROBY, H., 2009 Natural representation: diagram and text in Darwin's On the origin of species. Victorian studies 51 (2): 247-273.

BROWNE, J., 2009 Looking at Darwin: portraits and the making of an icon. Isis 100: 542-570.

BUFFON, G. L. L. and DAUBENTON, L. J. M., 1766 Histoire naturelle, générale et particulière, avec la description du Cabinet du Roy. Volume 14. Paris. 
COOK, R., 1974 The tree of life: image for the cosmos. London.

DARWIN, C., 1839 Narrative of the surveying voyages of His Majesty's Ships Adventure and Beagle between the years 1826 and 1836. Volume 3. London.

DARWIN, C., 1859 On the origin of species. London.

DESMOND, A., 1989 The politics of evolution: morphology, medicine, and reform in radical London. Chicago.

DESMOND, A. and MOORE, J., 2009 Darwin's sacred cause: race, slavery and the quest for human origins. London.

DOLITTLE, W. F., 1999 Phylogenetic classification and the universal tree. Science 284: 2124-2129.

DOLITTLE, W. F., 2000 Uprooting the tree of life. Scientific American 282 (2): 90-95.

DOLITTLE, W. F., 2010 The attempt on the life of the tree of life: science, philosophy and politics. Biology and philosophy 25 (4): 455-473.

GOULD, S. J., 1997 Ladders and cones: constraining evolution by canonical icons, pp 37-67 in SILVERS, R. B. (editor), Hidden histories of science. London.

GRUBER, H. E., 1978 Darwin's “Tree of Nature" and other images of wide scope, pp 120-140 in WECHSLER, J. (editor), On aesthetics in science. Cambridge, Massachusetts.

HAECKEL, E., 1874 Anthropogenie oder Entwickelungsgeschichte des Menschen: gemeinverständliche wissenschaftliche Vorträge über die Grundzüge der menschlichen Keimes- und Stammes-Geschichte. Leipzig.

HACKING, I., 2007 Trees of Logic, Trees of Porphyry, pp 219-261 in HEILBRON, J. L. (editor), Advancements of learning: essays in honour of Paolo Rossi. Florence.

HURST, G., 2009. Evolution to be compulsory subject in primary schools. The Times 20 November.

JAMES, E. O., 1966 The tree of life: an archaeological study. Leiden.

JOHNSON, J. R., 1961 The tree of Jesse window of Chartres: Laudes regiae. Speculum 36 (1): 1-22.

KLAPISCH-ZUBER, C., 1991 The genesis of the family tree. I Tatti studies: essays in the Renaissance 4: 105-129.

KLAPISCH-ZUBER, C., 2000 L'ombre des ancêtres: essai sur l'imaginaire médiéval de la parenté. Paris.

KLAPISCH-ZUBER, C., 2007 The tree, pp 293-314 in MOLHO, A., RAMADA CORTO, D. and KONIORDOS, N. (editors), Finding Europe: discourses on margins, communities, images ca. 13th-ca. 18th centuries. New York and Oxford.

KJAERGAARD, P., 2009 After the storm: parties and partisans in the Darwin year. Viewpoint 90 (October 2009): 1-3.

KOVATS, T. (editor), 2007 The drawing book: a survey of drawing: the primary means of expression. London.

KUNTZ, M. and KUNTZ, P., 1987 The symbol of the tree interpreted in the context of other symbols of hierarchical order, the great chain of being and Jacob's ladder, pp 319-334 in KUNTZ, M. L. and KUNTZ, P. G. (editors), Jacob's ladder and the tree of life: concepts of hierarchy and the great chain of being. New York.

LAMARCK, J.-B., 1809 Philosophie zoologique: ou exposition; des considérations relatives à l'histoire naturelle des animaux. Volume 2. Paris.

MacLEOD, R., 1965 Evolutionism and Richard Owen. Isis 56: 259-280.

MUSSELMAN, L. J., 2007 Figs, dates, laurel, and myrrh: plants in the Bible and the Quran. Portland, Oregon.

O'MALLEY, M. A., MARTIN, W. and DUPRÉ, J., 2010 The tree of life: introduction to an evolutionary debate. Biology and philosophy 25 (4): 441-453.

OSPOVAT, D., 1981 The development of Darwin's theory: natural history, natural theology, and natural selection, 1838-1859. Cambridge.

PALLAS, P. S., 1766 Elenchus zoophytorum, sistens generum adumbrationes generaliores et specierum cognitarum succintas descriptiones, cum selectis auctorum synonymis. The Hague.

RAGAN, M. A., 2009 Trees and networks before and after Darwin. Biology direct 4: 43.

RICHARDS, R. J., 2009 The tragic sense of life: Ernst Haeckel and the struggle over evolutionary thought. Chicago and London.

RUPKE, N. A., 1994 Richard Owen: Victorian naturalist. New Haven and London.

SCHAMA, S., 2004 Landscape and memory. London.

SECORD, J. A., 2009 Introduction to focus section on "Darwin as a cultural icon". Isis 100: 537-541. 
SHAPIN, S., 2010 The Darwin show. The London review of books 32 (1): 3-9.

STEARN, W. T., 1981 The Natural History Museum at South Kensington: a history of the British Museum (Natural History), 1753-1980. London.

STEVENS, P. F. and AUGIER, A., 1983 Augustin Augier's “Arbre Botanique” (1801), a remarkable early botanical representation of the natural system. Taxon 32 (2): 203-211.

VOSS, E. G., 1952 The history of keys and phylogenetic trees in systematic biology. Journal of the scientific laboratories of Denison University 43: 1-25.

VOSS, J., 2007 Darwins Bilder: Ansichten der Evolutionstheorie, 1837-1874. Frankfurt am Main.

VOSS, J., 2010 Darwin's pictures: views of evolutionary theory, 1837-1874. New Haven.

WATSON, A., 1934 The early iconography of the tree of Jesse. London.

YANNI, C., 1999 Nature's museums: Victorian science and the architecture of display. London.

Received 30 June 2010. Accepted 9 September 2010. 